Алексей Черный, священник ORCID: 0000-0002-7287-0860

Православный Свято-Тихоновский гуманитарный университет

Москва, Россия

\title{
«ГОСПОДСТВЕННАЯ ВЛАСТЬ» VS ДУШЕПОПЕЧЕНИЕ: ПРАКТИКА ИСПОВЕДИ В РУССКОЙ ДУХОВНОЙ ТРАДИЦИИ СИНОДАЛЬНОГО ПЕРИОДА
}

\author{
https://doi.org/10.34739/clit.2020.14.06
}

\begin{abstract}
“DESPOTICAL POWER" VS. COUNSELING: THE PRACTICE OF CONFESSION IN THE RUSSIAN SPIRITUAL TRADITION OF THE SYNODAL PERIOD
\end{abstract}

\begin{abstract}
The article attempts to reconstruct various pastoral models that appeared in the history of the Russian Orthodox Church over several centuries. The author identifies several "images" of confession, which are very different, among them: the realization of "despotical" power in a "confessional" family of the sixteenth century, the fulfillment of conscription, deeply personal interaction based on mutual trust and the value of a hierarchical aspect, counseling under the guidance of a "parish elder". The state, depending on the circumstances, either embeds the pastor in itself as a necessary part of its own mechanism, or considers the priesthood as a foreign element, or completely distances itself from religious affairs. The author suggests that the "types" of confession presented in the article can be compared with the forms of pastoral self-consciousness to be found in the modern life of the church. This in turn suggests that in the Russian Church today is characterized by the search for pastoral identity, in which the priesthood plays a key role.
\end{abstract}

Keywords: confession, priest, russian orthodox church, synodal period, pastoral counseling

Одной из важнейших задач христианского богословия с самых первых веков являлась подготовка священнослужителей. Эта задача всегда была и остается многоплановой и неформальной, поскольку она требует, с одной стороны, сохранения и передачи церковной традиции, а с другой - учета особых условий, в которых Церковь оказывается в ту 
или иную эпоху. В значительной степени именно в этом заключается специфика пастырской подготовки. Причем наиболее сложными и творческими оказываются те аспекты подготовки священника, которые связаны со взаимодействием с прихожанами. В связи с этим важно проанализировать развитие условий, в которых осуществлялось взаимодействие пастыря и пасомых, а также памятники церковной традиции - прежде всего, святоотеческие тексты, для которых характерна особая аксиоматика и которые позволяют делать выводы о непреходящих принципах, лежащих в основании церковного действия. В данной статье мы попытаемся проследить развитие взгляда на практику исповеди на примере трудов русских святых Синодальной эпохи.

\section{«Господственная» власть священника: Свт. Димитрий Ростовский (1651-1709)}

Можно сказать, что первым в России архиереем, обратившимся в посланиях к приходскому духовенству по такому деликатному вопросу, как общение с прихожанами в рамках исповеди был свт. Димитрий Ростовский. Он проводит четкую границу между священником, принимающим исповедь, и духовником (духовным отцом). В его представлении не всякий исповедующий священник является духовником. Также и не каждый христианин, регулярно участвующий в Таинстве Исповеди, по определению имеет духовника. В частности, это следует из его поучения Память духовному отцу как управить ставленника, в котором в качестве первого вопроса к кандидату на рукоположение назван вопрос о том, имеет ли ставленник духовного отца1? Также в Поучении к иереям² Димитрий Ростовский призывает священника: «не тщеславиться тем, что для кого-либо ты являешься духовным отцом и что такие-то твои духовные дети (...). Довольно с тебя того, что все приходящие в твою церковь люди знают тебя своим духовником»3. Здесь святитель подчеркивает, что во время исповеди священник «заступает место Самого Христа»4, но «если и дана от Бога иерею власть вязать и разрешать грехи, то эта власть действует только в то самое время, в которое совершается

\footnotetext{
${ }^{1}$ Амфилохий (Угличский), еп., Из неизданнъх сочинений Димитрия Ростовского, Санкт-Петербург 1889, с. 1.

2 Сочинения святого Димитрия, митрополита Ростовского: В 5 томах, Том I, содержащий в себе разные небольшие сего Святителя творения, с присовокуплением жития его и келейных записок, 6-е изд., Москва 1839, с. 159-168.

3 Ibidem, c. 165.

4 Ibidem, c. 161.
} 
Таинство Исповеди и покаяния, а после исповедания грехов духовник не должен вспоминать исповеданного, как и власти господственной над духовными детьми иметь не подобает»5.

Призыв святителя «не иметь господственной власти над духовными детьми» отражает реалии того времени: он стал свидетелем определенного кризиса института духовничества. В Эпоху, свидетелем завершения которой он стал, в отсутствии строго регламентированной приходской системы прихожане были свободны в выборе духовника, что, по мнению С. Смирнова, обуславливало ключевую роль «покаяльной семьи», отношения внутри которой простирались далеко за пределы границ прихода ${ }^{6}$ и не предусматривали вмешательства ни церковной, ни светской власти7. По аналогии с обыкновенной семьей, «покаяльная семья» подразумевала безусловное послушание главе и близкий к родственным характер отношений 8 . Почтение к духовнику должно было превосходить почтение к родному отцу, а тот, кто не слушает своего духовного отца, объявлялся даже «чуждым самого христианства»9. Сильным испытанием для института духовничества стала Смута и особенно Раскол, когда распространение автономных и неподконтрольных церковным властям «покаяльных семей» с непререкаемым авторитетом лидера оказалось одной из причин расцвета раскольнических сект, ориентированных на харизматическое лидерство и неизбежно ведущих к обособлению и дроблению на группы, атмосфера внутри которых целиком зависела от взглядов и качеств духовных лидеров ${ }^{10}$. Священноначалие, как правило, не обладало никакими инструментами влияния на такие общины. Свт. Димитрий, активно полемизировавший с раскольниками, настаивал на том, что далеко не каждый священник может претендовать на роль духовного отца. У него акцент переносится с личности духовника на таинство Исповеди, в котором, вне зависимости от того, какой священник его совершает, действует Святой Дух.

\section{Православное „левитство” XVIII века}

В допетровскую эпоху для осмысления социальной реальности, в том числе и для определения статуса священника, активно

\footnotetext{
5 Ibidem, c. 166.

${ }^{6}$ С. Смирнов, Древнерусский духовник, Москва 1913, с. 97-99.

7 Ibidem, c. 63.

${ }^{8}$ Ibidem, c. $52-55$.

9 Ibidem, c. 44.

${ }^{10}$ Ibidem, c. 85 .
} 
использовалась экзегеза Ветхого Завета. В Киевской Руси, которая в текстах своих книжников отождествляла себя с Новым Иерусалимом, священник походил на ветхозаветного «левита», который одновременно выделен в определенное колено, но и поставлен разделять быт народа, удерживать в нем благочестие, передаваемое в виде определенных норм. При Петре I государство требовало от священника, прежде всего, учить простой народ ${ }^{11}$ и через них старалось следить за соблюдением подданными норм благочестивого поведения, главной из которых была ежегодная практика говения: недельная подготовка к причастию, исповедь и Причащение. Эта практика являлась важным маркером религиозной жизни всех слоев русского общества, видимым образом смыкая различные сословия. При таких условиях обеспечение говения и исповеди было, наряду c просвещением народа, основной практикой пастырского служения.

В тексте Прибавления к Духовному регламенту присутствуют и другие требования к священнику, касающиеся поддержания стабильности в обществе и благонадежности прихожан, в первую очередь - обязанность бороться с расколом и предупреждать антигосударственные действия. Перед рукоположением ставленник должен публично проклясть раскольников и дать обещание докладывать о них епископу. В то же время будущий священник обязан принести присягу императору и пообещать сообщать о злоумышленниках (в том числе о тех, о которых священник узнал на исповеди) ${ }^{12}$. Интересно, что при этом неоднократно повторяется угроза строгого наказания за раскрытие тайны исповеди - таких священников предлагается лишать священства и подвергать мирскому суду и телесным наказаниям ${ }^{13}$.

Следует также отметить, что в этот период создаются предпосылки для создания приходской системы: высказывается намерение приписывать прихожан к конкретным церквам ${ }^{14}$. Приходским священникам запрещается совершать таинства и обряды для прихожан другого прихода. Помимо этого, они должны иметь у себя метрические книги и вести учет крещений, отпеваний и венчаний, отсылая данные раз в 4 месяца в архиерейские приказы,

\footnotetext{
${ }^{11}$ Ibidem, c. 322.

12 Духовный Регламент Всепресветлейшаго, Державнейшаго Государя Петра Перваго, Императора и Самодержца Всероссийскаго, Москва 1897, с. 98-100.

13 Ibidem, c. 97.

14 Ibidem, c. 110-111; В том же «свидетельстве, подписанном ставленником и прихожанами, определяется «руга» - земельный надел священнику, от которого тот будет кормиться.
} 
а те - в Синод 15 . Обязанность священников регистрировать акты гражданского состояния в определенном смысле сделала их государственными служащими. Однако контролю подверглось также совершение Таинства Исповеди, поскольку подразумевало отчет исповедующего священника. Священник должен был сообщать подробные сведения о явившихся и не явившихся на обязательную ежегодную Исповедь (с целью выявить раскольников), а также о готовящихся бунтах и антиправительственных настроениях. Это нередко приводило к конфликтам на местах и сообщало Таинству совершенно особенные негативные черты. Государственный контроль и придание Исповеди значения средства подтверждения благонадежности прихожан не способствовали доверительному отношению священника с паствой, подрывало авторитет духовенства и требовало дополнительных усилий для того, чтобы подчеркнуть духовное значение Исповеди ${ }^{16}$.

В Прибавлении довольно подробно осмысляются и различные аспекты практики Исповеди. В ряду «священнических должностей» называются обязанности «устрашать страшным судом тех, кто не раскаивается, отчаивающихся - укреплять милосердием Божиим, искоренять греховные обычаи, посещать и утешать больных, утверждать и напутствовать умирающих, обнадеживать милостью Божией ведомых на смерть»17. Пока не налажено образование духовенства, священникам рекомендуется записывать и заучивать наизусть (или даже зачитывать), что священник должен говорить в том или ином случае пастырской практики ${ }^{18}$.

Традиция таких «инструкций для духовников» получила в дальнейшем развитие в святоотеческой литературе Синодальной эпохи. Причем, обращает на себя внимание, с одной стороны, все более «профессиональный» характер таких текстов, а с другой - тот факт, что реализация духовной власти священника становится все более деликатной. Эти процессы удобно проследить на примере трудов свт. Тихона Задонского (1724-1783), ставшего епископом в 1762 г., в год восшествия на российский престол императрицы Екатерины II, когда во многом уже складываются отношения, установленные духовным Регламентом. В своем известном сборнике Должность

\footnotetext{
15 Ibidem, c. 113-114.

16 М.В. Пулькин, Таинство покаяния: проблемы осуществления в XVIII - начале XX в. (по материалам Олонецкой епархии), „Вестник Ленинградского государственного университета имени А.С. Пушкина, Серия История” 2010, № 02, c. 142.

17 Духовный Регламент, с. 96-97.

18 Ibidem.
} 
священническая 19 священник определяется как, прежде всего, «строитель Таинств Божиих» ${ }^{20}$, после чего следует перечисление основных канонических, преимущественно, формальных требований к ставленнику. В Прибавлении к Должности священнической ${ }^{21}$, в котором речь идет о том, как общаться с исповедующимися, характер изложения резко меняется. В самом начале мы читаем: «вначале со всякой кротостью, тихостью, как врачу душевному, увещевать, чтобы он все грехи объявил, какие после исповеди прежде бывшей содеял» ${ }^{22}$. Подчеркивается, что священник - лишь свидетель покаяния, грешный человек, подобный всем приходящим к нему: «Богу ты, чадо, исповедуешься (...) а я служитель Его недостойный и свидетель твоего покаяния (...) тебе подобострастен, такой же человек, как и ты»23. Для различных случаев на Исповеди святителем Тихоном предлагаются подробнейшие образцы, как уговаривать и увещевать, в каких случаях и каким образом проявлять строгость или мягкость 24. Однако, очевидно, здесь уже не возникает проблемы осуществления священником «господственной власти», что-либо подобное выглядело бы здесь даже неуместным: описываются гораздо более тонкие ментальные практики, свидетельствующие об определенных изменениях в обществе.

\section{«Филаретовское духовенство»: свт. Филарет Московский}

Наиболее выдяющийся богослов Синодальной эпохи - свт. Филарет Московский (1783-1867) - в отличие от своих предшественников, не оставил собственно пастырских посланий к духовенству. Более того, у читателя его работ легко может создаться ложное впечатление о нем как, преимущественно, о церковном управленце. В конце XIX - нач. XX вв. даже имело хождение особое выражение: «филаретовское духовенство», под которым подразумевались представители духовного сословия, крайне

19 Творения иже во святьх отца нашего Тихона Задонского, Издание пятое, Москва 1889 , c. $1-5$.

${ }^{20}$ Ibidem, c. 4.

${ }^{21}$ Ibidem, c. 6-9.

${ }^{22}$ Ibidem, c. 6.

23 Ibidem.

24 «Когда при исповеди заметишь, что исповедующийся сокрушается сердцем и печалится о грехах, то это хорошо, Богу благодарение! А если не заметишь в нем того сожаления и сердечного сокрушения, то всячески старайся к тому его привести, чтобы сожалел, что Бога такого благого, такого милостивого, такого великого благодетеля грехами прогневал. Что можешь и примером сделать, показывая свою сердечную болезнь о том, что мы все Бога прогневляем, и речь умилительную употребить», ibidem, с. 7. 
формально относящиеся к своему служению. Это было вызвано тем, что по своему положению свт. Филарет был вынужден, с одной стороны, наладить «систему» подготовки клириков и приходскую жизнь, a c другой - укреплять принцип иерархической подчиненности ${ }^{25}$, на который особенно ополчались раскольники. В связи с этим в его речах и проповедях в качестве важной задачи выявляется обоснование иерархической структуры Церкви, и, в первую очередь - пастырской власти епископа ${ }^{26}$.

Интересно, что необходимость соблюдения иерархического принципа связана у него не с тем, что всякий священник обязательно является сакральным лицом или духовно опытным человеком, а с тем, что такой порядок «назидательнее» для прихода ${ }^{27}$. Этой же причиной объясняется обязательное наличие границы пастырской юрисдикции в рамках исповеди, на которой настаивает святитель Филарет. Например, он настороженно относится к распространению пастырской литературы среди мирян. В частности, в отзыве на рукопись С. Струдзы «Письма о должностях священного сана» он пишет: «какое впечатление произведет в читателе светском, чтение особенно наставлений относящихся до исповеди? Не родится ли отсюда для него искушения смотреть на действия духовного отца, как на рассчитанные приемы искусства, и замечать, каково они употребляются, вместо того, чтобы внимать служителю таинств с благоговением и простотою?» 28 . По той же причине он выступает против обсуждения на приходских советах различных священнических нарушений, чтобы не вышло так, что «сегодня священник на исповеди будет судить совесть прихожанина, а завтра прихожанин будет судить священника по исполнении треб» 29.

25 Сочинения Филарета, митрополита Московского и Коломенского. Слова и речи, T. V, Москва 1885 , с. 328.

${ }^{26}$ Слово в день Алексия Митрополита, и в неделю сыропустную, [в:] Сочинения Филарета, митрополита Московского и Коломенского. Слова и речи, Т. II, Москва 1874, c. 42.

${ }_{27}$ Собрание мнений и отзывов, Т. V. Ч. 1, с. 293.

${ }^{28}$ Собрание мнений и отзывов, Т. III. с. 9.

29 Собрание мнений и отзывов, Т. V. Ч. 1, с. 294. Следует заметить, что в вопросе о церковных требах митр. Филарет придерживается мнения, что плата за требы вовсе не принижает священника и не делает из него наемного работника. Напротив, на основании Священного Писания он доказывает, что это благородно и традиционно как для христианской, так и для ветхозаветной традиции и важно для самих прихожан, которые «принимают участие в служении Богу, обеспечивая служащих Богу», ibidem; Также именно по пастырским соображениям он выступает против распространения в православной Церкви безбрачного духовенства, которое, по его мнению, будет неспособно окормлять семьи (Собрание мнений и отзывов, T. IV, с. 143). 
В резолюциях святителя чаще всего речь идет не о священнике как таковом, а о причте в целом, о духовенстве. Здесь священство рассматривается, прежде всего, как должность ${ }^{30}$. С другой стороны, понятие «духовник» или «духовный отец» лишь изредка употребляется митр. Филаретом в отдельных письмах, но никаких намеков на близкие отношения на подобии тех, что, согласно С. Смирнову, имели место в некоторых «покаяльных семьях» на Руси, мы не находим. В лучшем случае речь идет об исповедующем священнике. Однако гораздо чаще духовник выступает как официальная должность в учреждении ${ }^{31}$, либо как священник, обязанный проследить за тем, чтобы какое-либо важное дело прошло без злоупотреблений и без нарушений благочиния ${ }^{32}$. Яркий пример дело одного крестьянина, которого святитель предписывает вернуть из Москвы на родину, в Вятскую губернию, и «предоставить надзору местной полиции и отца духовного»33.

Власть над духовными детьми, которая по своему характеру могла бы быть охарактеризована как «господственная», усматривается митр. Филаретом только в среде раскольников, за православными же священниками он усматривает только «нравственное влияние» на прихожан ${ }^{34}$. Более того, он не предписывает мирянам искать сугубого духовного руководства со стороны священника, считая последнее естественным только для монашествующих. По его словам, миряне могут подчинить свою волю духовному руководителю, если только внутренне чувствуют особую нужду35. Однако пресвитер, с точки зрения свт. Филарета, даже если он действует как государственный «служащий», должен любой ценой удерживать контакт с прихожанами. Например, в связи с подготовкой освобождения крестьян он замечает, что священники могут лишь в некоторых случаях «оказывать некоторое споспешествование» 36 проведению

зо Действительно, в этот период священник уже никогда не избирается церковной общиной, а «определяется на священническое место», а провинившийся священник очень легко переводится на другую «должность» - причетническую (Собрание мнений и отзывов, Т. II, с. 241).

${ }^{31}$ К примеру, в комиссии духовных училищ (Собрание мнений и отзывов, Том I, с. 2).

$3^{2}$ Так, например, в резолюции еще архимандрита Филарета по делу некоей «солдатки» Мокеевой духовник упоминается как само собой разумеющееся лицо, однако ему отводится роль именно такого «надзирателя» (Собрание мнений и отзывов, Том I, c. 109).

33 Резолюции Филарета, Митрополита Московского, [в:] Душеполезное Чтение. Ежемесячное издание духовного содержания, Москва, Г. 21 (1980). Октябрь, с. 254.

34 Собрание мнений и отзывов..., Т. V. Часть 1, с. 313.

35 Слово в день Благовещения Пресвятыя Богородищы, [в:] Слова и речи..., ор. cit., Т. IV, c. 235 .

${ }^{36}$ Собрание мнений и отзывов, T. IV. C. 565. 
государственных реформ. Священник может действовать только «в свойственном ему характере»37, и не должен «вмешиваться в деятельность гражданскую» 38 . При необходимости во взаимодействие с гражданской властью вступает епископ, священник же всегда остается в границах пастырских задач. Эта ситуация очевидным образом выходит за рамки картины, описанной Духовным Регламентом.

\section{«Поворот к пастырству» второй половины XIX столетия}

Характер взаимоотношений между священником и паствой был вновь переосмыслен в конце XIX - нач. XX века в условиях увеличения социальной дифференциации населения, автономизации и индивидуализации жизни городского обывателя 39 . В этот период возникает новый тип городского священника, для которого стало невозможным ограничиваться поддержанием православного церковного быта («левитство»)40. В новых условиях от священника требовалась активная личная деятельность, инициатива в деле окормления и руководства церковной паствой, миссии среди малоцерковного городского населения. В частности, в этот период отдельные приходские священники начали настаивать на недостаточности говения единожды в год, что из предписанного минимума уже давно стало привычной нормой для большинства русских людей. Св. Иоанн Кронштадтский, протоиерей Валентин Амфитеатров и другие призывали прихожан к частой исповеди и причащению, а настоятель Маросейской общины св. Алексий Мечев работал над устроением монастыря в миру, т.е. общины, в основе которой лежали три элемента: богослужение, тесная и регулярная связь с духовником и послушание ${ }^{41}$. Две последние характеристики схожи с существенными чертами монашеского старчества древней Церкви, которые обозначил профессор В.И. Экземплярский в своем докладе Старчество в 1917 г.: обет послушания старцу и глубочайшая

\footnotetext{
37 Ibidem.

38 Ibidem.

39 Б. Миронов, Город из деревни: четыреста лет российской урбанизации, „Отечественные записки” 2012/3 (48), https://magazines.gorky.media/oz/2012/3/gorodiz-derevni-chetyresta-let-rossijskoj-urbanizaczii.html, [дата доступа: 12.11.2019].

40 П. Хондзинский, прот., Приходское духовенство конца XIX - начала XX века в русской духовной традиции, http://pstbi.ru/news/show/132-doklad_prot_Pavel_ Khondsinskiy, [дата доступа: 05.11.2019].

41 П. Хондзинский, свящ., Церковный быт и общинная жизнь (по трудам свщенномученика Сергия Мечева), „Politeja” 2012, № 19, с. 117-124.
} 
нравственная связь между старцем и учеником ${ }^{42}$. В этот период формируется новый для русской церковной традиции тип «приходского старца», осуществляющего душепопечение и духовное наставничество своей многочисленной паствы. Как следствие, из области верности благочестивому быту вопрос перемещается в область личного внутреннего подвига веры. Одновременно в качестве богословской темы возникает тема самопознания, что хорошо видно по дневникам св. Иоанна Кронштадтского 43 , который мог исповедовать одного человека в течение нескольких часов 44 . Показательно, что в это же время интенсивно развивается психология - как в университетской, так и в духовно-академической среде. Все это становится основой нового типа пастырства. Исповедальная практика в городах под влиянием «приходских старцев» второй половины XIX века претерпевает изменение: исповедь, которая во времена Петра I в некотором смысле стала актом подтверждения лояльности православному государству, при наличии неформального подхода со стороны самих пастырей становится необходимым средством духовного и молитвенного общения священника и его духовных чад, что позволяет говорить о возникновении «покаяльной» семьи нового типа, приобретшей новые черты уже в эпоху новомучеников.

\section{Заключение}

В данной статье мы попытались реконструировать различные пастырские модели, которые возникали в истории Русской Православной Церкви на протяжении нескольких веков и, в той или иной степени, стали частью современной картины русского пастырства. Мы видим несколько «образов» исповеди, весьма различных между собой: это и реализация «господственной» власти в «покаяльной» семье XVI века, и исполнение повинности, и глубоко личное взаимодействие, основанное на взаимном доверии и ценности иерархического начала. Наконец, во второй половине XIX века, в условиях постепенной смены общества традиции на общество модерна в России формируется новый тип священниковдушепопечителей, чей личный духовный подвиг акцентирует наше

\footnotetext{
42В. И. Экземплярский, Старчество, [в:] Дар ученичества, Сборник, сост. П.Г. Проценко, Москва 1993, с. 220-221.

43 См. П. Хондзинский, прот., Жизнь во Христе как предмет саморефлексии в дневниках святого Иоанна Кронштадтского, https://priest.today/news/hondzinskiyioann-kronshtadskiy-samorefleksiya, [дата доступа: 10.09.2019].

44Александр (Семенов-Тян-Шанский), еп. Отец Иоанн Кронштадтский, Нью-Йорк 1955, c. 74 .
} 
внимание на моральном и аскетическом аспектах пастырства. Показательно, что государство, в зависимости от обстоятельств, либо встраивало в себя пастыря как необходимую деталь собственного механизма, либо рассматривало священство как чужеродный элемент, либо полностью дистанцировалось от религиозных дел. В каждом случае государство в некотором роде провоцировало развитие новых форм пастырства. Представленные «типы» исповеди не остались лишь историческими пережитками: они являются типами пастырского самосознания, которые встречаются и сегодня. Это позволяет предположить, что в Русской Церкви происходит поиск пастырской идентичности, поиск ответа на вопрос, как Церкви в современных условиях остаться собой. Представляется, что именно священству принадлежит ключевая роль в этом поиске.

\section{Литература}

Александр (Семенов-Тян-Шанский), еп., Отец Иоанн Кронитадтский, Нью-Йорк 1955.

Амфилохий (Угличский), еп., Из неизданнъх сочинений Димитрия Ростовского, Санкт-Петербург 1889.

Антоний (Храповицкий), митр., Пастьцрккое богословие, Издание СвятоУспенского Псково-Печерского монастыря 1994.

Духовный Регламент Всепресветлейшаго, Державнейшаго Государя Петра Перваго, Императора и Самодержца Всероссийскаго, Москва 1897.

Миронов Б., Город из деревни: четьцеста лет российской урбанизации, „Отечественные записки” 2012/3 (48), https://magazines.gorky. media/oz/2012/3/gorod-iz-derevni-chetyresta-let-rossijskojurbanizaczii.html.

Практическое наставление пастырям, заимствованное с опыта. Из трудов святого праведного Иоанна Кронштадтского. Выдержки из дневниковых тетрадей за 186о-1865 годы, Москва 2013.

Пулькин М. В. Таинство покаяния: проблемы осуществления в XVIII начале XX в. (по материалам Олонецкой епархии), „Вестник Ленинградского государственного университета имени А.С. Пушкина, Серия История” 2010, № 02, с. 134-144.

Резолюции Филарета, Митрополита Московского, „Душеполезное Чтение. Ежемесячное издание духовного содержания” 1980, Г. 21, Октябрь, с. 249-254.

Смирнов С., Древнерусский духовник, Москва 1913.

Собрание мнений и отзывов Филарета, митрополита Московского u Коломенского, по учебньмм и церковно-государственнъмм вопросам, издаваемое под редакцией преосвященного Саввы, 
архиепископа Тверского и Кашинского, Т. V. Ч. 1., Санкт-Петербург 1887.

Собрание мнений и отзывов Филарета, митрополита Московского u Коломенского, по учебным и церковно-государственным вопросам, издаваемое под редакцией преосвященного Саввы, архиепископа Тверского и Кашинского, T. IV., Санкт-Петербург 1886.

Собрание мнений и отзывов Филарета, митрополита Московского и Коломенского, по учебным и церковно-государственным вопросам, издаваемое под редакцией преосвященного Саввы, архиепископа Тверского и Кашинского, Т. І., Санкт-Петербург 1885.

Сочинения святого Димитрия, митрополита Ростовского, В 5 томах, Том I, содержащий в себе разные небольшие сего Святителя творения, с присовокуплением жития его и келейных записок, 6-е изд., Москва 1839.

Сочинения Филарета, митрополита Московского и Коломенского. Слова и речи, Т. V, Москва 1885.

Сочинения Филарета, митрополита Московского и Коломенского. Слова и речи. T. IV, Москва 1882.

Сочинения Филарета, митрополита Московского и Коломенского. Слова и речи, Т. II, Москва 1874.

Стефанович П. С. Приход и приходское духовенство в Русской Церкви. XVIII-XIX вв., [в:] Православная энциклопедия, Том Русская Православная Церковъ, Москва 2000, с. 267-275.

Творения иже во святьхотца нашего Тихона Задонского, Издание пятое. Москва 1889.

Хондзинский П., прот., Жизнь во Христе как предмет саморефлексии в дневниках святого Иоанна Кронштадтского, https://priest.today/ news/hondzinskiy-ioann-kronshtadskiy-samorefleksiya.

Хондзинский П., прот., Приходское духовенство конца XIX - начала XX века в русской духовной традиции, http://pstbi.ru/news/show/ 132-doklad_prot_Pavel_Khondsinskiy.

Хондзинский П., свящ., Церковный быт и общинная жизнь (по трудам свщенномученика Сергия Мечева), „Politeja” 2012, № 19, c. 117-124.

Экземплярский В. И., Старчество, [в:] Дар ученичества, Сборник, сост. П.Г. Проценко, Москва 1993, с. 220-221.

\section{References}

Aleksandr (Semenov-Tyan-SHanskij), ep., Otec Ioann Kronshtadtskij, N'yuJork 1955.

Amfilohij (Uglichskij), ep., Iz neizdannyh sochinenij Dimitriya Rostovskogo, Sankt-Peterburg 1889.

Antonij (Hrapovickij), mitr., Pastyrskoe bogoslovie, Izdanie SvyatoUspenskogo Pskovo-Pecherskogo monastyrya 1994. 
Duhovnyj Reglament Vsepresvetlejshago, Derzhavnejshago Gosudarya Petra Pervago, Imperatora i Samoderzhca Vserossijskago, Moskva 1897.

Mironov B., Gorod iz derevni: chetyresta let rossijskoj urbanizacii, „Otechestvennye zapiski” 2012/3 (48), https://magazines.gorky. media/oz/2012/3/gorod-iz-derevni-chetyresta-let-rossijskojurbanizaczii.html.

Prakticheskoe nastavlenie pastyryam, zaimstvovannoe s opyta. Iz trudov svyatogo pravednogo Ioanna Kronshtadtskogo. Vyderzhki iz dnevnikovyh tetradej za 1860-1865 gody, Moskva 2013.

Pul'kin M.V., Tainstvo pokayaniya: problemy osushchestvleniya $v$ XVIII nachale $X X$ v. (po materialam Oloneckoj eparhii), „Vestnik Leningradskogo gosudarstvennogo universiteta imeni A.S. Pushkina, Seriya Istoriya” 2010, № 02, s. 134-144.

Rezolyucii Filareta, Mitropolita Moskovskogo, „Dushepoleznoe CHtenie. Ezhemesyachnoe izdanie duhovnogo soderzhaniya" 1980, G. 21, Oktyabr', S. 249-254.

Smirnov S., Drevnerusskij duhovnik, Moskva 1913.

Sobranie mnenij i otzyvov Filareta, mitropolita Moskovskogo i Kolomenskogo, po uchebnym i cerkovno-gosudarstvennym voprosam, izdavaemoe pod redakciej preosvyashchennogo Savvy, arhiepiskopa Tverskogo i Kashinskogo, T. V. CH. 1., Sankt-Peterburg 1887.

Sobranie mnenij i otzyvov Filareta, mitropolita Moskovskogo i Kolomenskogo, po uchebnym i cerkovno-gosudarstvennym voprosam, izdavaemoe pod redakciej preosvyashchennogo Savvy, arhiepiskopa Tverskogo $i$ Kashinskogo, T. IV., Sankt-Peterburg 1886.

Sobranie mnenij i otzyvov Filareta, mitropolita Moskovskogo i Kolomenskogo, po uchebnym i cerkovno-gosudarstvennym voprosam, izdavaemoe pod redakciej preosvyashchennogo Savvy, arhiepiskopa Tverskogo $i$ Kashinskogo, T. I., Sankt-Peterburg 1885.

Sochineniya svyatogo Dimitriya, mitropolita Rostovskogo, V 5 tomah, Tom I, soderzhashchij v sebe raznye nebol'shie sego Svyatitelya tvoreniya, s prisovokupleniem zhitiya ego i kelejnyh zapisok, 6-e izd., Moskva 1839. Sochineniya Filareta, mitropolita Moskovskogo i Kolomenskogo. Slova i rechi, T. V, Moskva 1885.

Sochineniya Filareta, mitropolita Moskovskogo i Kolomenskogo. Slova i rechi. T. IV, Moskva 1882.

Sochineniya Filareta, mitropolita Moskovskogo i Kolomenskogo. Slova i rechi, T. II, Moskva 1874.

Stefanovich P.S. Prihod i prihodskoe duhovenstvo v Russkoj Cerkvi. XVIII$-X I X v v$., [v:] Pravoslavnaya enciklopediya, Tom Russkaya Pravoslavnaya Cerkov', Moskva 2000, s. 267-275.

Tvoreniya izhe vo svyatyh otca nashego Tihona Zadonskogo, Izdanie pyatoe. Moskva 1889. 
Hondzinskij P., prot., ZHizn'vo Hriste kak predmet samorefleksii v dnevnikah svyatogo Ioanna Kronshtadtskogo, https://priest.today/news/ hondzinskiy-ioann-kronshtadskiy-samorefleksiya.

Hondzinskij P., prot., Prihodskoe duhovenstvo konca XIX - nachala XX veka $v$ russkoj duhounoj tradicii, http://pstbi.ru/news/show/132doklad_prot_Pavel_Khondsinskiy.

Hondzinskij P., svyashch., Cerkovnyj byt $i$ obshchinnaya zhizn' (po trudam svshchennomuchenika Sergiya Mecheva), „Politeja” 2012, № 19, S. 117-124.

Ekzemplyarskij V.I., Starchestvo, [v:] Dar uchenichestva, Sbornik, cost. P.G. Procenko, Moskva 1993, s. 220-221. 